\title{
Regular Physical Activity and Changes in Risk Factors for Coronary Heart Disease: A Nine Months Prospective Study
}

\author{
Gabriëlle A. E. Ponjee', Eugene M. E. Janssen ${ }^{2}$, Jo Hermans ${ }^{3}$ and Jan W. J. van Wersch ${ }^{4}$ \\ 1 Diagnostisch Centrum SSDZ, Delft, The Netherlands \\ 2 Nederlands Sports Instituut Geneeskunde, Arnhem, The Netherlands \\ 3 University of Leiden, Leiden, The Netherlands \\ 4 "De Wever" Ziekenhuis, Heerlen, The Netherlands
}

Summary: This study reports the non-acute effects of a long-term training programme of increasing intensity on some cardiovascular risk factors and the interrelation between these risk factors. Twenty sedentary men and 14 sedentary women were trained 3 to 4 times a week for nine months. After 36 weeks all individuals ran a half marathon run. The $\mathrm{W}_{\max }$, weight, body mass index, systolic and diastolic blood pressure were recorded. The concentrations of fibrinogen, tissue plasminogen activator, plasminogen activator inhibitor, triacylglycerols, total cholesterol, LDL cholesterol, HDL cholesterol and lipoprotein(a) were measured. The training programme induced a median increase in $\mathrm{W}_{\max }$ of $12 \%$ in the male group (from 226 to 251.5 Watt) and of $18 \%$ in the female group (from 160 to $188.5 \mathrm{Watt}$ ). These increases in $\mathrm{W}_{\max }$ did not correlate with any other property under investigation in this study. Blood pressure was not altered, but body weight and body mass index were significantly decreased in the male group (from 74.6 to $72.2 \mathrm{~kg}$ and from 23.1 to $22.0 \mathrm{~kg} / \mathrm{m}^{2}$, respectively) at the end of the training programme and decreased non-significantly in the female group (from 63.0 to $60.7 \mathrm{~kg}$ and from 21.6 to $21.5 \mathrm{~kg} / \mathrm{m}^{2}$, respectively). In the male group total cholesterol, low density lipoprotein cholesterol and triacylglycerols decreased significantly under the influence of the training sessions. Furthermore, in both groups, a great decrease in plasma plasminogen activator inhibitor concentrations was noticed: in men from $22.5 \cdot 10^{3} \mathrm{AU} / 1$ to $4.5 \cdot 10^{3} \mathrm{AU} / 1$ and in women from $18.7 \cdot 10^{3} \mathrm{AU} / 1$ to $5.1 \cdot 10^{3} \mathrm{AU} / \mathrm{l}$. However, the changes in the lipid and fibrinolytic quantities were not correlated with each other. Initial total cholesterol, LDL cholesterol and triacylglycerol levels correlated significantly with systolic blood pressure, while diastolic pressure was correlated to tissue plasminogen activator. Since tissue plasminogen activator also was significantly related to triacylglycerols, a trias existed between primary risk factors like blood pressure, lipid levels and fibrinolysis. In contrast, the changes in these properties under the influence of physical training were not interrelated. Median serum lipoprotein(a) concentrations were significantly increased in both men and women five days before the half marathon run: from $32 \mathrm{mg} / 1$ to $39 \mathrm{mg} / \mathrm{l} \mathrm{in} \mathrm{men}$, and from $65 \mathrm{mg} / 1$ to $125.5 \mathrm{mg} / \mathrm{l}$ in women. Concomitantly, median fibrinogen concentrations were significantly elevated in men (from $2.32 \mathrm{~g} / 1$ to $3.10 \mathrm{~g} / \mathrm{l}$ ) and non-significantly in women (from $2.62 \mathrm{~g} / 1$ to $2.93 \mathrm{~g} / \mathrm{l}$ ), although no correlation existed between the changes in these properties.

In conclusion, the nine months exercise programme increased the aerobic fitness in both men and women as indicated by the $\mathrm{W}_{\max }$ increase. This improvement coincided but was not correlated with beneficial changes in several anthropometric, lipid and fibrinolytic properties. Improvement in the risk factors under investigation was more pronounced in men than in women. The changes in lipid and haemostasis properties did not correlate with each other. The increases in lipoprotein(a) and fibrinogen concentrations, both atherogenic indices, could actually present a normal physiological response to the physical strain of exercise training of increasing workload.

\section{Introduction}

Atherosclerosis leading to coronary heart disease is still the major cause of morbidity and mortality in our Western society (1). Atherosclerosis is a complex multifactorial disorder, but the pathogenesis includes a contributing role for blood lipids and haemodynamic forces $(1-3)$. Occlusion of an atherosclerotic vessel, based on thrombus formation, links the haemostatic system with atherosclerosis at a fundamental level $(2-4)$. Risk factors for atherosclerosis are several anthropometric determinants like sex, age, body weight and blood pressure $(5-8)$. In addition, various biochemical quantities contribute to the formation of atherosclerotic plaques of 
which hyperlipidaemia, namely an increased serum total and/or low density lipoprotein cholesterol (LDL cholesterol) is the best known $(7-10)$. Other properties include factors of the haemostatic system, like an elevated plasma fibrinogen or plasminogen activator inhibitor concentration (11-13). Recently lipoprotein(a), an LDL-like lipoprotein with a great homology to plasminogen, a component of the haemostatic system, was designated as an independent risk factor for the genesis of artherothrombotic disease (14-17). Regular physical exercise, among other life-style habits like diet and a history of no smoking, may reduce the risk of vascular thrombotic events $(6,18-21)$. This protection might be mediated through the effect of exercise on the haemostatic system and the lipid metabolism, because endurance trained athletes exhibit generally more favourable values of haemostatic and lipidic variables than their non-active counterparts $(22-25)$. The results of longitudinal studies, in which selection bias and constitutional factors have been minimized, are difficult to compare due to differences in e.g. duration and intensity of the exercise programmes $(23,26-30)$. Only few studies exist on the interrelation of anthropometric, lipid and haemostatic risk factors and the potentially favourable effect of long-term moderate exercise on these properties $(31-33)$.

The present study was designed to investigate the nonacute effect of long-term physical conditioning on anthropometric and biochemical quantities in previously sedentary men and women and to evaluate the relationship between the studied components.

\section{Materials and Methods}

\section{Subjects}

Three hundred seventy people replied to advertisements in two local newspapers and on a local radio station. Those who participated in any sports such as running or jogging or who were active for more than one hour per week in other recreational sports were excluded. From the remaining group, twenty males aged from 32 to 49 years (median: 39 years) and 14 females aged from 27-41 years (median: 35 years) were aselectly chosen to participate in the study. No lipid lowering or antihypertensive medication was used by any of the volunteers. Among the participants were three female and six male cigarette smokers (maximum of ten cigarettes a day), who continued to smoke during the test period. All individuals kept their diet and other living habits, like the use of alcohol, as constant as possible during the study. After two information sessions all subjects gave their written informed consent.

\section{Training programme}

After a medical examination and pre-exercise control measurements, all volunteers participated in a 9 months endurance training programme preparing for a half marathon run $(21 \mathrm{~km})$. The training period lasted 9 months. After 24 and 36 weeks of training all subjects ran a $15 \mathrm{~km}$ and $21 \mathrm{~km}$ race, respectively. During the general preparation period the volunteers trained 3-4 times a week; 6 weeks before each contest the training programme was intensified to 5-6 times a week. Beside the attention paid to style and tech- nique of running, stretching, speed, intervals, warming-up and cooling-down, the training included three elements: long-distance running, running at high speed and interval training. The elements followed each other naturally as far as the intensity is concerned. The intensity was for long-distance runs $70-80 \%$ of maximal heart rate, for running at a fixed pace $80-85 \%$ of maximal heart rate (over 200-2000 $\mathrm{m}$ depending on the training status) and for intervals over shorter distances $(200-400 \mathrm{~m}) 95-100 \%$ of maximal heart rate. By putting these three elements together (in relation of $70: 20: 10$ of the distances per week) a gradual undulating increase of the amount of training can be accomplished by training to a maximum of 60 min per training sessipn in the first part of the study and to a maximum of 100 min per training session in the second part (34).

\section{Sampling}

All blood samples were drawn between 8.00 and 9.00 a.m. All subjects were seated and had not eaten or exercised during the preceding ten hours before phlebotomy. Samples were taken before the start of the training programme and, in order to avoid acute effects, five days before both races. Non-traumatic venipuncture was performed by trained technicians. Within one hour from sample collection serum was separated from blood, snap-frozen in aliquots, stored at $-70^{\circ} \mathrm{C}$ in plastic tubes and thawed at $37^{\circ} \mathrm{C}$ immediately prior to serial analysis.

\section{Blood pressure}

Blood pressure was determined using a standard auscultatory method by a skilled technician, after a five-minutes rest period of the subjects in supine position. For the systolic blood pressure the first Korotkoff sounds were noted, while the diastolic blood pressure was measured at the disappearance of the Korotkoff sounds.

\section{Graded maximal exercise tolerance test}

Exercise tolerance test was conducted using a Lode bicycle ergometer. The test started at a workload of 50 Watt. After a warmingup period of 10 minutes, the exercise intensity was increased by 50 Watt every 4 minutes until exhaustion. During the test, subjects cycled at a rate of approximately $80 \mathrm{~min}^{-1}$ and heart rate was monitored continuously. $\mathrm{W}_{\max }{ }^{1}$ ) was calculated as the power step at which was cycled for the complete 4 minutes, plus the fraction of power cycled in the final intensity step.

\section{Laboratory procedures}

Fibrinogen was determined according to the Clauss method (intraassay CV 3.2\%; (35)). Reference values, determined in plasma from 50 healthy volunteers ranged from 2.0 to $4.0 \mathrm{~g} / \mathrm{l}$. The antigen concentrations of the following properties were determined using an ELISA test method: Tissue plasminogen activator (Kabi Vitrum Diagnostica, Molndal, Sweden, intra-assay CV 4.9\%) and lipoprotein(a) (Biopool AB, Umea, Sweden) $(36,37)$. Reference range for tissue plasminogen activator, determined in plasma of 50 healthy volunteers (males and females) was: $0.9-12.1 \mu \mathrm{g} / \mathrm{l}$. The lipoprotein(a) assay included ready to use micro-test plates containing affinity purified sheep anti-apolipoprotein(a) Ig and sheep anti-apolipoprotein(a) peroxidase conjugated Ig (37). Reference range, determined in serum from 50 healthy volunteers was $0-300 \mathrm{mg} / \mathrm{l}$. The intra-assay coefficient of variation was $3.1 \%$ at a concentration of $150 \mathrm{mg} / \mathrm{l} \mathrm{Lp}(\mathrm{a})$ and $4.8 \%$ at a concentration of $65 \mathrm{mg} / \mathrm{l} \mathrm{Lp}(\mathrm{a})$. Plasminogen activator inhibitor activity was analyzed using an excess single chain tissue plasmogen activator and S-2251 as a chromogenic substrate for plasmin (Kabi Vitrum Diagnostica, intra-assay CV 9.5\%; (38)). Reference ranges determined in 50 healthy volunteers were: $\left.10.7-32.7 \cdot 10^{3} \mathrm{AU} / \mathrm{l}^{1}\right)$. Serum triacylglycerols (reference range: $0.8-2.0 \mathrm{mmol} / \mathrm{l}$ ) and total cholesterol (reference

\footnotetext{
l) $W_{\max }=$ maximum work load
} $\mathrm{AU}=$ arbitrary units 
range: $4.0-7.5 \mathrm{mmol} / \mathrm{l}$ ) were determined using enzymatic assays (Roche Diagnostica, Basel, Switzerland and Boehringer Mannheim, respectively). High density lipoprotein cholesterol (HDL cholesterol fraction was isolated from serum by the phosphostungstic acid/magnesium chloride precipitant and determined with a test kil of Boehringer (39), reference range: $0.9-1.7 \mathrm{mmol} / 1$. Low density lipoprotein cholesterol (LDL cholesterol) was calculated according to the Friedewald equation (40), reference range : 3.0-5.0 $\mathrm{mmol} / \mathrm{h}$. For all assays of lipids and lipoproteins the intra-assay coefficients of variation was less than $5 \%$.

\section{Statistics}

All statistic computations were done with SPSS/PC+ Statistics 4.0 computer package (SPSS Inc., Chicago, USA). Wilcoxon signed rank test was used to compare differences in pre- and post-exercise plasma samples. The Mann-Whirney test was used to compare the male and female population. All data are given as medians and interquartile ranges. Correlations between changes in lipids, lipoproteins and haemostatic factors and changes in anthropometric values were calculated according to the method of Spearman (stepwise). Multiple regression was carried out to find independent determinants for the variations in the increase of $\mathrm{W}_{\max }$.

\section{Results}

\section{Effect of training on maximal workload and the risk factor profiles}

Median (interquartile range) initial anthropometric determinants, values of the lipid metabolism, the haemo-

Tab. 1 Median (interquartile range) initial anthropometric characteristics and variables of the lipid metabolism and haemostatic

Men static and fibrinolytic system and the changes in these properties after nine months of training are summarized in table 1 . In both men and women a nine month training programme produced a significant increase in $\mathrm{W}_{\max }$.

In men this increase was 24 Watt $=12 \%(p<0.001)$ (median change from 226 to 251.5 Watt) and in women 25 Watt $=18 \%$ (n.s.) (median change from 160 to 188.5 Watt). In men the median diastolic blood pressure at rest before and after the training programme was 80 $\mathrm{mm} \mathrm{Hg}$. In women median diastolic pressure was shifted from 72.5 to $77.5 \mathrm{~mm} \mathrm{Hg}$ (n. s.). In men the median systolic blood pressure at rest before the training programme was $132.5 \mathrm{~mm} \mathrm{Hg}$ and 9 months later $130 \mathrm{~mm}$ $\mathrm{Hg}$ (n. s.). In women the systolic blood pressure shifted from $120 \mathrm{~mm} \mathrm{Hg}$ to $125 \mathrm{~mm} \mathrm{Hg}$ (n.s.). The median (interquartile range) body weight shifted in the male population from $74.6(69.1-79.8) \mathrm{kg}$ at start to 72.2 $(64.8-77.7) \mathrm{kg}(\mathrm{p}<0.01)$ at the end of the training programme. In the female population from 63.0 (57.0$65.8) \mathrm{kg}$ to 60.7 (55.0-63.4) kg (n. s.). The median (interquartile range) body mass index shifted in the male group from $23.1(21.6-25.5) \mathrm{kg} / \mathrm{m}^{2}$ to $22.0(21.1-24.4)$ $\mathrm{kg} / \mathrm{m}^{2}(\mathrm{p}<0.01)$ and in the female group from 21.6 $(21.3-22.6) \mathrm{kg} / \mathrm{m}^{2}$ to $21.5(21.3-22.3) \mathrm{kg} / \mathrm{m}^{2}$ (n.s.). The lipids showed a significant $(p<0.01)$ decrease in

system in men and women and the changes in six months (prepost) for these properties.

\begin{tabular}{|c|c|c|c|c|c|}
\hline & $\mathrm{n}$ & Initial & & Change & p-value \\
\hline $\mathrm{W}_{\max }(\mathrm{Watt})$ & 20 & 226 & $(203-266)$ & $24.0(8.5-42.0)$ & $\mathrm{p}<0.001$ \\
\hline Weight (kg) & 20 & 74.6 & $(69.1-79.8)$ & $-1.6(-3.0-(0.2))$ & $\mathrm{p}<0.001$ \\
\hline Body mass index $\left(\mathrm{kg} / \mathrm{m}^{2}\right)$ & 20 & 23.1 & $(21.6-25.5)$ & $-0.5(-0.9-0.0)$ & $\mathrm{p}<0.001$ \\
\hline Diastolic blood pressure (mm $\mathrm{Hg}$ ) & 20 & 80 & $(80-81)$ & $0.0(-5.0-0.0)$ & $\mathrm{p}=0.27$ \\
\hline Systolic blood pressure $(\mathrm{mm} \mathrm{Hg})$ & 20 & 133 & $(129-146)$ & $-7.5(-15.0-0.0)$ & $p=0.06$ \\
\hline Fibrinogen $(\mathrm{g} / \mathrm{l})$ & 18 & 2.32 & $(1.97-2.48)$ & $0.78(0.50-1.02)$ & $\mathrm{p}<0.001$ \\
\hline Tissue plasminogen activator $(\mu \mathrm{g} / \mathrm{l})$ & 19 & 5.8 & $(4.7-8.4)$ & $0.10(-2.10-(-0.60))$ & $\mathrm{p}=0.48$ \\
\hline Plasminogen activator inhibitor $\left(10^{3} \mathrm{AU} / \mathrm{l}\right)$ & 17 & 22.5 & $(16.0-26.8)$ & $-13,5(-17.5-(-7.0))$ & $\mathrm{p}=0.001$ \\
\hline Triacylglycerols $(\mathrm{mmol} / \mathrm{l})$ & 20 & 1.1 & $(0.9-1.5)$ & $-0.33(-0.40-(-0.07))$ & $\mathrm{p}=0.001$ \\
\hline Total cholesterol $(\mathrm{mmol} / \mathrm{l})$ & 19 & 5.8 & $(5.0-6.4)$ & $-0.45(-1.15-(-0.2))$ & $\mathrm{p}<0.001$ \\
\hline LDL cholesterol $(\mathrm{mmol} / \mathrm{l})$ & 19 & 4.0 & $(3.3-4.8)$ & $-0.50(-1.01-(-0.28))$ & $\mathrm{p}=0.001$ \\
\hline HDL cholesterol $(\mathrm{mmol} / \mathrm{l})$ & 19 & 1.0 & $(0.9-.13)$ & $0.0(-0.10-0.10)$ & $\mathrm{p}=0.75$ \\
\hline Lipoprotein(a) (mg/l) & 20 & 32 & $(11-63)$ & $39.0(25.0-68.0)$ & $\mathrm{p}<0.001$ \\
\hline
\end{tabular}

Women

\begin{tabular}{|c|c|c|c|c|c|}
\hline & $\mathrm{n}$ & Initial & & Change & $\mathrm{p}$-value \\
\hline $\mathrm{W}_{\max }($ Watt $)$ & 14 & 160 & $(152-175)$ & $25.0(17.5-38.5)$ & $p=0.016$ \\
\hline Weight (kg) & 14 & 63.0 & $(57.0-65.8)$ & $-0.7(-2.0-0.5)$ & $\mathrm{p}=0.10$ \\
\hline Body mass index $\left(\mathrm{kg} / \mathrm{m}^{2}\right)$ & 14 & 21.6 & $(21.3-22.6)$ & $-0.2(-0.7-0.2)$ & $\mathrm{p}=0.14$ \\
\hline Diastolic blood pressure (mm $\mathrm{Hg})$ & 14 & 73 & $(70-80)$ & $0.0(-5.0-10.0)$ & $\mathrm{p}=0.35$ \\
\hline Systolic blood pressure (mm Hg) & 14 & 120 & $(115-130)$ & $5.0(-2.5-10.0)$ & $p=0.25$ \\
\hline Fibrinogen $(g / 1)$ & 14 & 2.62 & $(2.13-3.01)$ & $0.31(-0.21-0.72)$ & $\mathrm{p}=0.06$ \\
\hline Tissue plasminogen activator $(\mu \mathrm{g} / \mathrm{l})$ & 14 & 3.7 & $(2.7-7.0)$ & $0.45(-1.70-2.60)$ & $p=0.57$ \\
\hline Plasminogen activator inhibitor $\left(10^{3} \mathrm{AU} / \mathrm{l}\right)$ & 11 & 18.7 & $(16.0-25.5)$ & $-12.5(-15.6-(-9.6))$ & $\mathrm{p}=0.003$ \\
\hline Triacylglycerols $(\mathrm{mmol} / \mathrm{l})$ & 14 & 0.9 & $(0.7-1.1)$ & $-0.10(-0.24-0.10)$ & $p=0.28$ \\
\hline Total cholesterol $(\mathrm{mmol} / \mathrm{l})$ & 14 & 5.3 & $(3.9-6.0)$ & $-0.40(-1.13-0.08)$ & $p=0.16$ \\
\hline LDL cholesterol $(\mathrm{mmol} / \mathrm{l})$ & 14 & 3.2 & $(2.5-3.9)$ & $-0.24(-0.79-0.10)$ & $p=0.22$ \\
\hline HDL cholesterol $(\mathrm{mmol} / \mathrm{l})$ & 14 & 1.5 & $(1.1-1.9)$ & $-0.10(-0.25-0.10)$ & $p=0.18$ \\
\hline Lipoprotein(a) (mg/l) & 14 & 65 & $(23-199)$ & $65.5(31.8-283.3)$ & $\mathrm{p}<0.001$ \\
\hline
\end{tabular}


triacylglycerols, total cholesterol, and low density lipoprotein cholesterol (LDL cholesterol) in the male group, but not in the female population. In contrast, $L p(a)$ concentrations were significantly $(p<0.01)$ higher in both men and women after the completion of the training programme. In the male group, fibrinogen concentrations were significantly $(p<0.01)$ raised after nine months, while in the female group the rise in median fibrinogen concentration was not significantly different from pretraining levels. Finally, in both men and women a large and highly significant $(p<0.001)$ decrease in median plasminogen activator inhibitor levels was observed after nine months of training.

\section{Correlation analysis}

Table 2 shows the correlation (Spearman) between the change in $\mathrm{W}_{\max }$ and the change in the studied properties after nine months of training in men and women. No significant relation existed between the increase in maximal workload on a cycle ergometer and the change in

Tab. 2 Spearman's rank coefficient of correlation ( $r$ ) between the change in $\mathrm{W}_{\max }$ and the change in the variables of the risk factor profile after nine months of training.

\begin{tabular}{|c|c|c|c|c|}
\hline \multirow[t]{2}{*}{ Change in } & \multicolumn{2}{|c|}{ Men } & \multicolumn{2}{|c|}{ Women } \\
\hline & $\mathrm{N}$ & $\mathbf{r}$ & $\mathrm{N}$ & $\mathbf{r}$ \\
\hline Weight (kg) & 20 & 0.04 & 14 & 0.48 \\
\hline Body mass index $\left(\mathrm{kg} / \mathrm{m}^{2}\right)$ & 20 & 0.04 & 14 & 0.42 \\
\hline $\begin{array}{l}\text { Diastolic blood pressure } \\
\text { (mm Hg) }\end{array}$ & 20 & -0.12 & 14 & -0.32 \\
\hline $\begin{array}{l}\text { Systolic blood pressure } \\
\text { (mm Hg) }\end{array}$ & 20 & 0.15 & 14 & 0.03 \\
\hline Fibrinogen $(\mathrm{g} / \mathrm{l})$ & 18 & 0.07 & 14 & 0.15 \\
\hline $\begin{array}{l}\text { Tissue plasminogen } \\
\text { activator }(\mu \mathrm{g} / \mathrm{l})\end{array}$ & 19 & -0.21 & 14 & -0.16 \\
\hline $\begin{array}{l}\text { Plasminogen activator } \\
\text { inhibitor }\left(10^{3} \mathrm{AU} / \mathrm{l}\right)\end{array}$ & 16 & -0.01 & 10 & -0.57 \\
\hline Triacylglycerols (mmol/l) & 19 & -0.47 & 14 & 0.24 \\
\hline Total cholesterol (mmol/l) & 19 & -0.04 & 14 & -0.36 \\
\hline LDL cholesterol (mmol/1) & 19 & -0.15 & 14 & -0.24 \\
\hline HDL cholesterol $(\mathrm{mmol} / \mathrm{l})$ & 19 & 0.36 & 13 & -0.02 \\
\hline Lipoprotein(a) (mg/l) & 20 & 0.005 & 14 & 0.18 \\
\hline
\end{tabular}

atherogenic determinants. Table 3 shows the correlations between initial anthropometric and biochemical quantities for the total group. Diastolic blood pressure was significantly correlated with tissue plasminogen activator concentration in serum $(r=0.46, p<0.01)$ while systolic blood pressure related significantly to total cholesterol $(r=0.55, p<0.001)$, LDL cholesterol $(r=0.58, p<0.001)$ and triacylglycerols $(r=0.60$, $\mathrm{p}<0.001)$. Triacylglycerols also çorrelated significantly with body mass index $(r=0.46, p<0.01)$. Correlation analysis between initial values of the haemostatic and fibrinolytic system and lipid metabolism showed a significant relation between tissue plasminogen activator and serum triacylglycerols $(r=0.60$, $\mathrm{p}<0.001$ ). Finally, the correlation (Spearman) between changes in lipid and lipoprotein metabolism with changes in the haemostatic and fibrinolytic system for the total group are shown in table 4. No significant relation was found between changes in these biochemical quantities.

\section{Multiple regression}

In the stepwise multiple regression model, dependent variable was the change in $\mathrm{W}_{\max }$ after nine months $\left(\Delta \mathrm{W}_{\max }\right)$. Independent variables for $\Delta \mathrm{W}_{\max }$ were initial body weight, body mass index, diastolic and systolic blood pressure. Using these independent variables, the regression equation had an $\mathrm{R}^{2}$ value of $0.33(\mathrm{~N}=34)$. In the stepwise multiple regression model however, no independent variables were selected for $\Delta \mathrm{W}_{\max }$.

\section{Discussion}

Several epidemiological studies have revealed that a sedentary lifestyle is an independent risk factor for coronary heart disease, while habitual physical activity may reduce the individual risk for this condition $(6,18-21)$. The protective effect of exercise seems to be mediated through favourable influences on several established anthropometric and biochemical risk factors $(19,27,33)$.

Tab. 3 Spearman's rank coefficient of correlation between initial anthropometric variables and initial blood properties in the total group $(\mathrm{N}=34)$.

\begin{tabular}{|c|c|c|c|c|c|c|}
\hline & $\begin{array}{l}\text { Age } \\
\text { (a) }\end{array}$ & $\mathrm{W}_{\max }$ & Weight & $\begin{array}{l}\text { Body } \\
\text { mass } \\
\text { index } \\
\left(\mathrm{kg} / \mathrm{m}^{2}\right)\end{array}$ & $\begin{array}{l}\text { Diastolic } \\
\text { blood } \\
\text { pressure } \\
\text { (mm Hg) }\end{array}$ & $\begin{array}{l}\text { Systolic } \\
\text { blood } \\
\text { pressure } \\
\text { (mm Hg) }\end{array}$ \\
\hline Fibrinogen $(g / l)$ & 0.02 & -0.39 & -0.18 & 0.12 & 0.09 & 0.01 \\
\hline Tissue plasminogen activator $(\mu \mathrm{g} / \mathrm{l})$ & 0.29 & 0.13 & 0.34 & 0.32 & $0.46^{\mathrm{a}}$ & 0.39 \\
\hline Plasminogen activator inhibitor $\left(10^{3} \mathrm{AU} / \mathrm{n}\right)$ & -0.10 & 0.07 & 0.36 & 0.21 & 0.08 & 0.03 \\
\hline Triacylglycerols (mmol/l) & 0.19 & 0.17 & 0.36 & $0.46^{\mathrm{a}}$ & 0.32 & $0.60^{\mathrm{b}}$ \\
\hline Total cholesterol $(\mathrm{mmol} / \mathrm{l})$ & 0.32 & -0.02 & 0.05 & 0.27 & 0.19 & $0.55^{\mathrm{b}}$ \\
\hline LDL cholesterol (mmol/l) & 0.41 & 0.14 & 0.20 & 0.36 & 0.28 & $0.58^{\mathrm{b}}$ \\
\hline HDL cholesterol (mmol/l) & 0.13 & -0.37 & -0.39 & -0.12 & -0.25 & 0.02 \\
\hline Lipoprotein(a) (mg/l) & -0.09 & -0.17 & -0.15 & 0.05 & -0.12 & 0.14 \\
\hline
\end{tabular}

${ }^{\mathrm{a}} \mathrm{P}<0.01 ;{ }^{\mathrm{b}} \mathrm{p}<0.001$ 
Tab. 4 Spearman's rank coefficient of correlation between changes $(\Delta)$ in quantities of the lipid metabolism and changes $(\Delta)$

in factors of the haemostatic and fibrinolytic system after nine months of training in the total group $(\mathrm{N}=34)$.

\begin{tabular}{|c|c|c|c|c|c|}
\hline & $\begin{array}{l}\Delta \text { Triacyl- } \\
\text { glyerols } \\
(\mathrm{mmol} / \mathrm{l})\end{array}$ & $\begin{array}{l}\Delta \text { Total } \\
\text { cholesterol } \\
(\mathrm{mmol} / \mathrm{l})\end{array}$ & $\begin{array}{l}\Delta \text { Low density } \\
\text { lipoprotein } \\
\text { cholesterol } \\
(\mathrm{mmol} / \mathrm{l})\end{array}$ & $\begin{array}{l}\Delta \text { High density } \\
\text { lipoprotein } \\
\text { cholesterol } \\
(\mathrm{mmol} / \mathrm{l})\end{array}$ & $\begin{array}{l}\Delta \text { Lipo- } \\
\text { protein(a) } \\
(\mathrm{mg} / \mathrm{l})\end{array}$ \\
\hline $\begin{array}{l}\Delta \text { Fibrinogen }(\mathrm{g} / \mathrm{l}) \\
\Delta \text { Tissue plasminogen activator }(\mu \mathrm{g} / \mathrm{l}) \\
\Delta \text { Plasminogen activator inhibitor }\left(10^{3} \mathrm{AU} / \mathrm{l}\right)\end{array}$ & $\begin{array}{r}0.24 \\
0.09 \\
-0.15\end{array}$ & $\begin{array}{l}-0.13 \\
-0.04 \\
-0.06\end{array}$ & $\begin{array}{r}-0.13 \\
0.28 \\
0.08\end{array}$ & $\begin{array}{r}0.29 \\
-0.16 \\
0.15\end{array}$ & $\begin{array}{r}-0.19 \\
-0.03 \\
0.10\end{array}$ \\
\hline
\end{tabular}

Vigourous physical activity may directly or indirectly influence body weight, blood pressure and the lipid status $(22,24)$. Furthermore, beneficial effects of intensive exercise on the haemostatic system are described $(23,25)$. Nowadays, whether the intensity of exercise training, attainable for the majority of people, will provoke similar results, is a topic of investigation $(6,10$, $28,32,41,42)$.

In our study a nine months exercise programme of moderate intensity resulted in a median $\mathrm{W}_{\max }$ increase of 24 Watt $(12 \%)$ in men and 25 Watt $(18 \%)$ in women. Although aerobic fitness is commonly expressed as maximal oxygen uptake $\left(\mathrm{VO}_{2_{\max }}\right), \mathrm{W}_{\text {max }}$ is a more stable determinant for aerobic endurance capacity and easier to assess in the laboratory (43). Results of other studies, in which previously sedentary individuals participated in an aerobic training programme of moderate intensity, showed increases in $\mathrm{VO}_{2_{\max }}$ of $10-20 \%(30,41,42)$. These results are comparable with the results of the present study, since $\mathrm{VO}_{2_{\max }}$ and $\mathrm{W}_{\text {max }}$ are linearly interrelated $(43,44)$. The nine months training programme provoked, besides increases in $W_{\max }$ at all participants, several changes in selected risk factors. However, the change in aerobic endurance capacity was not significantly correlated with changes in anthropometric variables or changes in lipid and haemostatic properties. Furthermore, in the stepwise multiple regression model, no initial anthropometric variables were independent predictors for the changes of $\mathrm{W}_{\max }$. So, an active life style and physical conditioning by itself influences risk factors, irrespective of anthropometric characteristics or the outcome of the training sessions $(10,12,20,27,45)$. Regular physical activity can lower mean resting blood pressure in moderately hypertensive patients, although this finding is not universal (46-48). In our study, no significant changes were found in diastolic or systolic blood pressure at the end of the training programme in either men or women. However, one can doubt whether a fall in blood pressure in healthy normotensive subjects is likely to be expected $(41,42,43,49)$. The nine months training programme induced a significant decrease in median body weight and body mass index in the male group, as well as a non-significant reduction of body weight and body mass index in the female group. This finding can be explained by the increased energy expenditure of the individuals under investigation as a result of the regular training sessions $(24,33)$. Before the training programme, initial total cholesterol, LDL cholesterol and triacylglycerol levels correlated significantly with the systolic blood pressure in the total group, while the diastolic blood pressure was significantly correlated to tissue plasminogen activator. Furthermore, a significant relation between tissue plasminogen activator and triacylglycerols was found. Hypofibrinolysis in patients with hyperlipidaemia has been frequently reported (5053). Also a high blood pressure seems to influence fibrinolysis $(54,55)$. The results of the present study focus on the important interplay between primary risk factors, like blood pressure and lipid levels with fibrinolysis (54). The changes in the haemostatic, fibrinolytic and lipid status as a result of long-term training programme has been separately discussed before $(56-59)$. The fall in plasma plasminogen activator inhibitor levels, observed in both men and women and the significant decrease in total cholesterol, LDL cholesterol and triacylglycerols in the group of men after nine months of training are known favourable effects of physical conditioning $(26,27,30,33,63)$. The changes in these variables were not interrelated, stressing the fact that these properties as risk factors for atherosclerotic disease behave independently (61). Lipoprotein(a), an LDL like lipoprotein, competes with plasminogen for fibrin binding in vitro, and therefore may relate atherosclerosis to thrombosis (14-17). Although some studies report an association between lipoprotein(a) levels and fibrinogen concentrations, most investigators failed to find any relation between lipoprotein(a) and factors of the haemostatic or fibrinolytic system (62-64). Also in the present study, the increases in lipoprotein(a) levels in both groups and the increases in fibrinogen levels in the male group at the end of the training programme were not correlated. Lipoprotein(a) levels are often increased in patients suffering from coronary heart disease $(16,65)$. Recently lipoprotein(a) levels in sera of healthy physically active individuals were found to be raised, which parallels the results of the present study (66). Therefore, lipoprotein(a) may play a physiological role as an acute phase reactant in tissue repair, making its function not solely restricted to be an atherogenic determinant (66, 
67). In the present study, the training sessions in preparation for the half marathon run probably have caused physical stress on the body of the participants, inducing a rise in lipoprotein(a) and also in fibrinogen as acute phase reactants $(66-69)$. Finally, the present study was restricted to a selected group of healthy volunteers and most pretraining metabolic properties of the individuals were in the normal reference range. Therefore the impact of the results of this training programme could only be limited. Taking this in consideration, the effect of physical conditioning on the risk factor profile should be more pronounced in individuals with slight to moderate increased risk to cardiovascular disease. Further research on this subject should therefore include patients with an elevated

\section{References}

1. Ross R. The pathogenesis of atherosclerosis - an update. N Engl J Med 1986; 314:488-500.

2. Badimon JJ. Fuster V, Chesebro JH, Badimon L. Coronary atheroslcerosis; a multifactorial disease. Circulation 1993; 87 (II Suppl):35-165.

3. Strong JP. Atherosclerotic lesions; natural history, risk factors, and topography. Arch Pathol Lab Med 1992; 116:1268-75.

4. Von Rokitansky C. A manual of pathological anatomy. London, England: Sydenham Society 1852; 4:261.

5. Al-Hazzaa HM, Sulaiman MA, Al-Matar AJ, Al-Mobaireek KF. Cardiorespiratory fitness, physical activity patterns and coronary risk factors in preadolescent boys. Int J Sport Med 1994: 15:267-72.

6. Paffenbarger RS, Hyde RT, Wing AI, Lee IM, Jung DL, Kampert JB. The association of changes in physical-activity level and other lifestyle characteristics with mortality among men. N Engl J Med 1993; 328:538-45.

7. Håheim LL, Holme I, Hjermann I, Leren P. Risk factors of stroke incidence and morality; a 12-year follow-up of the Oslo study. Stroke 1993; 24:1484-9.

8. Marti B, Suter E, Riesen WF, Tschopp A, Wanner HU. Anthropometric and lifestyle correlates of serum lipoprotein and apolipoprotein levels among normal non-smoking men and women. Atherosclerosis 1989; 75:111-22.

9. Hostmark AT, Berg J, Brudal S, Berge SR, Kierulf P, Bjerkedal $T$. Coronary risk factors in middle-aged men as related to smoking, coffee intake and physical activity. Scand J Soc Med 1992; 20:196-203.

10. Adamopoulos PN, Macrilakis K, Papamichael Ch, Malakos I, Panaydis N, Moulopoulos SpD. Physical activity and relationship with coronary heart disease risk factors. Acta Cardiol 1993; 6:523-34.

11. Hamsten A, Walldius G, Szamosi A, Blombäck M, De Faire $U$, Gahlén $G$, et al. Plasminogen activator inhibitor in plasma: risk factor for recurrent myocardial infarction. Lancet 1987; i:3-9.

12. Elwood PC, Yarnell JWG, Pickering J, Fehily AM, O'Brien JR. Exercise, fibrinogen, and other risk factors for ischaemic heart disease. Caerphilly prospective Heart Disease Study. Br Heart J 1993; 69:183-7.

13. Ernst E, Resch KL. Fibrinogen as a cardiovascular risk factor: a meta-analysis and review of the literature. Ann Int Med 1993; 118:596-63.

14. Edelberg J, Pizzo SV. Why is lipoprotein(a) relevant to thrombosis? Am J Clin Nutr 1992; 56:791S-2S.

15. Loscalzo J, Weinfeld M, Fless GM, Scanu AM. Lipoprotein(a), fibrin binding, and plasminogen activation. Arteriosclerosis $1990 ; 10: 240-5$.

16. Rosengren A, Wilhelmsen L, Eriksson E, Risberg B, Wedel H. Lipoprotein(a) and coronary heart disease: a prospective casecontrol in a general population sample of middle aged men. Br Med J 1990; 301:1248-51. risk factor profile. Furthermore, longer exercise programmes and larger study groups may be needed to get effects comparable with cross-sectional studies.

In conclusion, the results of the present study show that regular physical conditioning of moderate intensity influences coronary risk factors at rest. These changes are more pronounced in men than in women. Improvement of anthropometric factors, lipid profile and fibrinolytic potential are important favourable effects. Supposed adverse effects of exercising, like increases in lipoprotein(a) and fibrinogen, could actually be a normal physiological response to the physical strain of the exercise programme of increasing workload.

17. Hajjar KA, Gavish D, Breslow JL, Nachman RL. Lipoprotein(a) modulation of endothelial cell surface fibrinolysis and its potential role in atherosclerosis. Nature 1989; 339:303-5.

18. Ekelund LG, Haskell WL, Johnson JL, Whaley FS, Criqui $\mathrm{MH}$, Sheps DS. Physical fitness as a predictor of cardiovascular mortality in asymptomatic North American men. N Engl J Med 1988; 319:1379-84.

19. Bovens AM, van Baak MA, Vrencken JG, Wijnen JA, Saris WH, Verstappen FT. Physical activity, fitness, and selected risk factors for CHD in active men and women. Med Sci Sports Exerc 1992; 5:572-6.

20. Bijnen FCH, Caspersen CJ, Mosterd WL. Physical inactivity as a risk factor for coronary heart disease: a WHO and International Society and Federation of Cardiology position statement. Bulletin WHO 1994; 72:1-4.

21. Lakka TA, Venäläinen JM, Rauramma R, Salonen R, Tuomolehto J, Salonen JT. Relation of leisure-time physical activity and cardiorespiratory fitness to the risk of acute myocardial infarction in men. N Engl J Med 1994; 330:1549-54.

22. Mena P, Maynar M, Campillo JE. Plasma lipid concentrations in professional cyclists after competitive cycle races. Eur J Appl Physiol 1991; 62:349-52.

23. Streiff $M$, Bell WR. Exercise and hemostasis in humans. Semin Hematol 1994; 31:155-65.

24. Stray-Gundersen J, Denke MA, Grundy SM. Influence of lifetime cross-country skiing on plasma lipids and lipoproteins. Med Sci Sports Exerc 1991; 23:695-701.

25. Gough SCL, Whitworth S, Rice PJS, Grant PJ. The effect of exercise and heart rate on fibrinolytic activity. Blood Coagul Fibrinol 1992; 8:179-82.

26. Després JP, Tremblay A, Moorjani S, Lupien PJ, Thériault G, Nadeau A, et al. Long-term exercise training with constant energy intake. 3: effects on plasma lipoprotein levels. Int J Obes $1990 ; 14: 85-94$.

27. Findlay IN, Taylor RS, Dargie HJ, Grant S, Pettigrew AR, Wilson JT, et al. Cardiovascular effects of training for a marathon run in unfit middle aged men. $\mathrm{Br}$ Med $\mathrm{J}$ 1987; 295:521-4.

28. Superko HR. Exercise training, serum lipids, and lipoprotein particles: is there a change threshold? Med Sci Sports Exerc $1991 ; 23: 677-85$.

29. Thompson PD, Cullinane EM, Sady SP, Flynn MM, Bernier DN, Kantor MA, et al. Modest changes in high-density lipoprotein concentration and metabolism with prolonged exercise training. Circulation 1988; 78:25-34.

30. Stratton JR, Chandler WL, Schwartz RS, Cerqueira MD, Levy WC, Kahn SE, et al. Effects of physical conditioning on fibrinolytic variables and fibrinogen in young and old healthy adults. Circulation 1991; 83:1692-7.

31. Krobot K, Hense HW, Cremer P, Eberle E, Keil U. Determinants of plasma fibrinogen: relation to body weight, waist-to- 
hip ratio, smoking, alcohol, age, and sex. Arteriosclerosis Thromb 1992; 12:780-8.

32. Young DR, Haskell WL, Jatulis DE, Fortmann SP. Associations between changes in physical activity and risk factors for coronary heart disease in a community-based sample of men and women: the Stanford Five-City project. Am J Epidemiol 1993; 138:205-16.

33. Wood PD. Stefanick ML, Dreon DM, Frey-Hewitt B, Caray SC, Willialms PT, et al. Changes in plasma lipids and lipoproteins in overweight men during weight loss through dieting as compared with exercise. N Engl J Med 1988; 319:1173-9.

34. Janssen GME. Marathon running: functional changes in male and female subjects during training and contests. Int J Sport Med 1989; 10 Suppl 3:117-90.

35. De Metz $M$, van Wersch JWJ. Use of a centrifugal analyzer for a chromogenic prothrombin time, a chromogenic activated partial thromboplastin time and a kinetic fibrinogen assay in a routine hospital laboratory. Haemostasis 1987; 17:254-9.

36. Rijken DC, Juhan-Vague I. DeCock F, Collen D. Mcasurement of human tissue-type plasminogen activator by a two-site immunoradiometric assay. J Lab Clin Med 1983; 101:274.

37. Brändstorm $A$, Johnson $O$, Dahlen G, Ranby M. Lp(a) levels in a healthy population measured by a new enzyme linked immuno sorbent assay [abstract]. Thromb Haemost 1989; 62:573.

38. Chmielewska J, Wiman B. Determination of tissue plasminogen activator and its 'fast' inhibitor in plasma. Clin Chem 1986; $32: 482-5$.

39. Seigler L, Wu WT. Separation of serum high-density lipoprotein for cholesterol determination: ultracentrifugation vs precipitation with sodium phosphotungstale and magnesium chloride. Clin Chem 1981; 27:838-41.

40. Friedewald WT. Levy RI, Frederickson DS. Estimation of the concentration of low-density-lipoprotein cholesterol in plasma without use of the preparative ultracentrifuge. Clin Chem $1972 ; 18: 499-509$.

41. Grant S, Aitchison T, Pettigrew AR, Orrell JM. The effects of a university fitness programme on health-related variables in previously sedentary males. Br J Sports Med 1992; 26:39-44.

42. Stein PK, Boutcher SH. The effect of participation in an exercise training program on cardiovascular reactivity in sedentary middle-aged males. Int J Psychophysiol 1992; 13:215-23.

43. Arts FJP, Kuipers H. The relation between power output, oxygen uptake and heart rate in male athletes. Int $\mathrm{J}$ Sports Med $1994 ; 15: 228-31$.

44. Hawley JA, Noakes TD. Peak power output predicts maximal oxygen uptake and performance time in trained cyclists. J Appl Physiol 1992; 65:79-83.

45. Hellénius ML, de Faire U, Berglung B, Hamsten A, Krakau I. Diet and exercise are equally effective in reducing risk for cardiovascular disease. Results of a randomized controlled study in men with slightly to moderately raised cardiovascular risk factors. Atheroslcerosis 1993; 103:81-91.

46. Gordon NF, Scott CB. Exercise and mild essential hypertension. Primary Care 1991; 18:683-94.

47. Blumenthal JA, Siegel WC, Appelbaum M. Failure of exercise to reduce blood pressure in patients with mild hypertension. $J$ Am Med Ass 1991; 266:2098-104.

48. Seals DR, Hagberg JM. The effect of exercise training on human hypertension: a review. Med Sci Sports Exerc 1984; 16:207-15.

49. Gilders RM, Voner C, Dudley GA. Endurance training and blood pressure in normotensive and hypertensive adults. Med Sci Sports Exerc 1989; 21:629-36.

50. Greig HBW, Glasg MB. Inhibition of fibrinolysis by alimentary lipaemia. Lancet $1956 ; \mathrm{i}: 16-8$.

51. Donders SHJ, Lustermans FATh, van Wersch JWJ. Fibrinolysis factors and lipid composition of the blood in treated and un- treated hypertensive patients. Blood Coagul Fibrinol 1992; 3:61-7.

52. Mehta J, Mehta P, Lawson D, Saldeen T. Plasma tissue plasminogen activator inhibitor levels in coronary artery disease: correlation with age and serum triglyceride concentrations. J Am Coll Cardiol 1987; 9:263-8.

53. Andersen P. Hypercoagulability and reduced fibrinolysis in hyperlipidaemia: relationship to the metabolic cardiovascular syndrome. J Cardiovascular Pharmacol 1992; 20 (Suppl 8):295-315.

54. Jansson JH, Johansson B, Boman K, Nilsson TK. Hypofibrinolysis in patients with hypertension and elevated cholesterol. J Int Med 1991; 229:309-16.

55. Urano T, Kojima Y, Takahashi M, Serizawa K, Sakakibara K, Takada Y, et al. Impaired fibrinolysis in hypertension and obesity due to high plasminogen activator inhibitor-1 level in plasma. Jpn J Physiol 1992; 43:221-8.

56. Ponjee GAE, Janssen GME, van Wersch JWJ. Prolonged endurance exercise and blood coagulation: a 9 month prospective study. Blood Coagul Fibrinol 1993; 4:21-5.

57. Ponjee GAE, Janssen GME, van Wersch JWJ. Effect of longterm endurance exercise on fibrinolytic markers. Fibrinolysis $1993 ; 7: 397-400$.

58. Ponjee GAE, Janssen GME, Hermans J, Van Wersch JWJ. Effects of long-term exercise of moderate intensity on anthropometric values and serum lipids and lipoproteins. Eur J Clin Chem Clin Biochem 1995; 33:121-6.

59. Ponjee GAE, Janssen GME, Van Wersch JWJ. Long-term exercise and lipoprotein(a) levels in a previously sedentary male and female population. Ann Clin Biochem. 1995; 32:181-5.

60. Gris JC, Schved JF, Aguilar-Martinez P, Arnaud A, Sanchez N. Impact of physical training on plasminogen activator inhibitor activity in sedentary men. Fibrinolysis 1990; 4 Suppl 2:97-8.

61. De Geus EJC, Kluft C, De Bart ACW, VanDoornen LJP. Effects of exercise training on plasminogen activator inhibitor activity. Med Sci Sports Exerc 1992; 24:1210-9.

62. Heinrich J, Sandkamp M, Kokott R, Schulte H, Assmann G. Relationship of lipoprotein(a) to variables of coagulation and fibrinolysis in a healthy population. Clin Chem 1991; 37:1950-4.

63. Glueck CJ, Glueck HI, Tracy T, Speirs J, McGray C, Stroop D. Relationships between lipoprotein(a), lipids, apolipoproteins, basal and stimulated fibrinolytic regulators, and D-dimer. Metabolism 1993; 42:236-46.

64. Halvorsen S, Skønsberg OH, Berg K, Ruyter R, Godal HC. Does $L p(a)$ lipoprotein inhibit the fibrinolytic system? Thromb Res 1992; 68:223-32.

65. Oshima S, Uchida K, Yasu T, Uno K, Nonogi H, Haze K. Transient increase of plasma lipoprotein(a) in patients with unstable angina pectoris. Arterioscler Thromb 1991; 11:1772-7.

66. Cardoso GC, Posadas C, Orvanaños OO, Peniche C, Zamora J, Aguilar R, et al. Long distance runners and body-builders exhibit elevated plasma levels of lipoprotein(a). Chem Phys Lipids 1994; 67/68:207-21.

67. Craig WY, Ledue TB. Lipoprotein(a) and the acute phase response. Clin Chim Acta 1992; 210:231-2.

68. Arai M, Yorifuji H, Ikematsu S, Nagasawa H, Fujimaji M, Fukutake $\mathrm{K}$, et al. Influences of strenuous exercise (triathlon) on blood coagulation and fibrinolytic system. Throm Res 1990; 57:465-71.

69. Taniguchi N, Hirohiko, Yamauchik. Effects of treadmill exercise on platelet functions and blood coagulating activities in healthy men. Jpn Heart J 1984;26:167-80.

Received December 2. 1994/September 4, 1995

Corresponding author: G. A. E. Ponjee. Diagnostisch Centrum SSDZ, P. O. Box 5010, NL-2600 GA Delft, The Netherlands 
